\title{
EFFECT OF POSITION OF FRUITS IN A TREE AND NUMBER OF FRUITS PER PANICLE ON GROWTH AND QUALITY OF CITRUS
}

\author{
Research note \\ SAKHIDIN $^{1 *}$, Jaime A. TEIXEIRA da SILVA ${ }^{2}$, Slamet Rohadi SUPARTO $^{1}$ \\ ${ }^{1}$ Faculty of Agriculture, Jenderal Soedirman University, Karangwangkal, 53123 Purwokerto, Indonesia \\ ${ }^{2}$ Independent, Ikenobe 3011-2, Kagawa-ken, 761-0799, Japan \\ Received: January 2018; Accepted: May 2018
}

\begin{abstract}
This research aimed to study the effect of the position of fruits in a tree (inner or outer) and the number of fruits per panicle (one, two or three) on the growth and quality of citrus 'Pontianak'. The study was conducted in a citrus orchard in Central Java, Indonesia for two seasons, 2014/2015 and 2015/2016. The results indicated that position of fruits on the tree did not influence weight and diameter of fruits, weight of fruit pulp, and contents of sugars and total acids. Increasing the number of fruits per panicle decreased the weight and diameter of fruits and the weight of pulp but increased the contents of vitamin $\mathrm{C}$ and total acids.
\end{abstract}

Key words: citrus, outer and inner fruits, fruits number per panicle, quality

\section{INTRODUCTION}

Fruits of Citrus nobilis 'Pontianak' have several human health-related benefits (Ezeigbo et al. 2013). Vitamin $C$ is the most important element and its content can be affected by preharvest conditions (Magwaza et al. 2017). Citrus fruit grows terminally and is distributed randomly in a tree canopy, and fruits on outer shoots are exposed to higher light intensity (and temperature) than inner ones. Outer fruits at the perimeter of the tree canopy receive $100 \%$ light intensity, whereas inner fruits only receive about $30 \%$ of full light intensity. There is a two- to four-fold increase in leaf photosynthetic capacity from the bottom to the top of the canopy (Meir et al. 2002; Massot et al. 2013). Differences in light intensity and temperature influence the growth and quality of citrus fruit, mainly vitamin C content (Dhillon \& Thakur 2014).

The number of young fruits per panicle in citrus varies and can also influence the growth of fruits and the final yield from a tree. So it is important to regulate the optimum number of fruits per panicle by thinning fruitlets, as was shown for apple (Volz et al. 1993). Falivene and Hardy (2008) reported an increase in fruit size in citrus by hand thinning and by regulating the optimum number of fruitlets per panicle because an increase in photosynthesis efficiency. Moreover, an excessive crop load will increase the risk of breaking the tree (Ouma 2012).

The objective of this study was to evaluate the effect of the position of fruit in a tree and the number of fruits per panicle on growth and quality (primarily vitamin $\mathrm{C}$ content) of citrus fruits.

\section{MATERIALS AND METHODS}

The study was conducted in a citrus orchard belonging to a private owner in Kembangan Village, Bukateja District, Purbalingga Regency, Central Java, Indonesia, for two seasons, 2014/2015 and 2015/2016, from October until August. The geographic coordinates of the study's location, which was at $60 \mathrm{~m}$ asl, are $7.44^{\circ} \mathrm{S}$ and $109.43^{\circ} \mathrm{E}$. Soil of plots contained $0.132 \%$ total nitrogen $(\mathrm{N}), 0.069 \%$ $\mathrm{P}_{2} \mathrm{O} 5$, and $0.057 \% \mathrm{~K}_{2} \mathrm{O}$. At this location, the rainy season is from October until April, whereas the dry season is from April to October. The average rainfall 
was $136 \mathrm{~mm}$ per month, average air temperature of 24-36 ${ }^{\circ} \mathrm{C}$, and average sunshine was seven $\mathrm{h}$ per day, as measured at a local meteorological station. A total of 36 four-year-old trees of Citrus nobilis 'Pontianak' with uniform growth were used in both seasons. The trees received agricultural treatments typical for this locality.

The experiment was designed as two-factorial with a completely randomized design. The first factor was the position of fruits in a tree, outer or inner. The second factor was the number of fruits per panicle - one, two, or three. Each treatment contained six replications. On an average, 20 panicles out of about 60 usually growing on the tree were selected, and the initial fruit density per tree was about 120 (21 days after flower petals senesce). At this time, the number of fruits per panicle was one, two, or three. Four fruits or more per panicle was a very scarce phenomenon. The vast majority of citrus fruits grow and develop outside, but about $20 \%$ of fruits grow inside the crowns. Fruitlets were thinned manually to leave one, two, or three per panicle inside and outside. Outer fruits were at the surface so they received $100 \%$ light intensity $\left(1550 \mu \mathrm{mol} \cdot \mathrm{m}^{-2} \cdot \mathrm{s}^{-1}\right)$ whereas inner fruits were shaded by leaves so they received about $30 \%$ light intensity $\left(\sim 465 \mu \mathrm{mol} \cdot \mathrm{m}^{-2} \cdot \mathrm{s}^{-1}\right)$, as measured with a LX-101 A light meter (Lutron Electronic Enterprise Co. Ltd., Taipei, Taiwan).

All citrus trees were irrigated using furrow irrigation along tree rows. Applied fertilizer dosage was based on the yield of harvested citrus fruit (3\% of weight) and the added nutrients per tree were $473 \mathrm{~g}$ $\mathrm{N}, 332 \mathrm{~g} \mathrm{P}_{2} \mathrm{O}_{5}$, and $95 \mathrm{~g} \mathrm{~K}_{2} \mathrm{O}$ (Sutopo 2011). N was applied as urea fertilizer (PT Pupuk Sriwidjaja, Palembang, Indonesia), $\mathrm{P}_{2} \mathrm{O}_{5}$ was supplied as SP36 and $\mathrm{K}_{2} \mathrm{O}$ was supplied as ZK (PT Petrokimia, Gresik, Indonesia). Fertilizers were applied twice, at first as $50 \%$ of the dosage after harvest, and the remainder four months later. No serious pests or diseases were detected, so no pesticides were applied. The observed variables were fruit weight determined on each of 36 trees in each season at harvest. Twenty fruits were harvested from each tree to measure diameter with a vernier caliper, and pulp and peel weight $(w / w)$. In these fruits organoleptic properties (total sugars, total acids, and vitamin $\mathrm{C}$ content) were evaluated. The contents of total sugars and total acids were evaluated using a colorimetric method, according to Sudarmadji et al. (1989) with a UV-Vis spectrophotometer (UV mini-1240, Shimadzu, Kyoto, Japan). Vitamin C was measured by a titrimetric method (Sudarmadji et al. 1989). Data were analyzed statistically by two-way analysis of variance (ANOVA), separately for each year of study. Means were separated using the least significant difference $(\mathrm{LSD})$ test $(\mathrm{p}=0.05)$.

\section{RESULTS AND DISCUSSION}

The weight and diameter of fruits were not dependent on their position on the tree (Table 1). In contrast, the number of fruits per panicle influenced fruit weight and diameter. The difference in weight between fruits grown as single and as three on a panicle was $18 \%$ (Table 1). Three fruits per panicle produced fruits with diameter smaller by a $7 \%$ in comparison with fruits grown as a single (Table 1). There were no differences in fruit weight and diameter between fruits grown as one or two per panicle. Similarly, Rahmawan et al. (2015) noted that the average weight of citrus fruit when panicles had one or two fruits was the same, so trees did not required thinning. Moreover, weight of fruits grown in three per panicle inside the crowns was bigger than those grown outside (data not showed). The most likely reason is that inner grown fruits had lower transpiration and higher water content in their shaded leaves. In mango, Lechaudel et al. (2013) noted a significant decrease in water conductance of well-exposed outer fruits compared to inner fruits within the canopy and, depending on the position of fruit - on or within the canopy, the temperature gradient affected transpiration, as revealed by the water potential gradient. Thinning is a procedure that is frequently applied in citrus fruit production (Guardiola \& García-Luis 2000; Iglesias et al. 2007; Ouma 2012; Zhou et al. 2014). Thanks to this procedure more photosynthesis products become available for the remaining fruitlets thus leading to an increase in the fruit weight and size. In contrast, in pummelo Nartvaranant (2016) found that thinning fruitlets by $50 \%$ did not affect fruit weight but increased fruit retention percentage. Fruit 
thinning has been the subject of study in apple production (Racskó 2006; Stover 2000). Thinning fruits within clusters effectively increased fruit size, indicating that fruit distribution, as well as total number of fruits, was crucial to determine apple size of 'Cox's Orange Pippin' (Dennis 2000).

Pulp and peel weight were not influenced by fruit position (Table 2). In contrast, weight of pulp of fruits grown as three per panicle was 19\% smaller and fruits grown in two 15\% smaller than those grown as a single, reflecting the influence of fruitlet number on whole fruit weight (Table 1). Weight of peel was not affected by fruit position nor the number per panicle.

Neither the position of the fruit in the tree crown nor the number of fruits per panicle influenced total sugar content (Table 3). Total acids content was $30 \%$ higher in fruits grown as three than single and $28 \%$ higher than in fruits grown as two per panicle. Vitamin C content was influenced by fruit position and number of fruits per panicle. Inner fruits had $15 \%$ lesser vitamin $C$ content than outer fruits. Fruits grown in two or three contained 10\% more vit. $\mathrm{C}$ than those grown as single (Table 3 ).

Our study shows that the evaluated organoleptic properties of citrus fruit were dependent on fruit position on the tree and on the number of fruits per panicle. In our earlier report, we showed that total sugar content in one, two, or three fruits per panicle did not differ in citrus 'Pontianak' (Rahmawan et al. 2015). Similar to our experiment, Lee and Kader (2000) found that fruits on the outside of the canopy exposed to maximum sunlight contained more vitamin $C$ than fruits on the inside or shaded fruits on the same plant. Ghani et al. (2016) and Ezeigbo et al. (2013) found that many factors affect vitamin C content, one of them being the position of fruit on a tree.

Table 1. Effect of the position of fruits in the citrus tree and the number of fruits per panicle on the fruit weight ( $\mathrm{g}$ ) and diameter $(\mathrm{mm})$ - means from two seasons. In brackets percent of difference

\begin{tabular}{ccccc}
\hline \multirow{2}{*}{$\begin{array}{c}\text { Position of fruits } \\
\text { in tree }\end{array}$} & \multicolumn{2}{c}{ Weight of fruit $(\mathrm{g})$} & \multicolumn{2}{c}{ Fruit diameter $(\mathrm{mm})$} \\
\cline { 2 - 5 } Outer & $2014 / 2015$ & $2015 / 2016$ & $2014 / 2015$ & $2015 / 2016$ \\
\hline Inner & $109 \pm 8.57^{\mathrm{a}}$ & $109 \pm 8.45^{\mathrm{a}}$ & $61.0 \pm 2.89^{\mathrm{a}}$ & $61.1 \pm 2.83^{\mathrm{a}}$ \\
\hline$F$ value & $111 \pm 8.58^{\mathrm{a}}$ & $111 \pm 8.47^{\mathrm{a}}$ & $61.9 \pm 2.90^{\mathrm{a}}$ & $62.0 \pm 2.84^{\mathrm{a}}$ \\
\hline $\begin{array}{c}\text { Number of fruits } \\
\text { per panicle }\end{array}$ & $0.20^{\mathrm{ns}}$ & $0.19^{\mathrm{ns}}$ & $0.64^{\mathrm{ns}}$ & $0.75^{\mathrm{ns}}$ \\
\hline 1 & & & \\
& & & & \\
\hline 3 & $119 \pm 8.98^{\mathrm{b}}$ & $119 \pm 8.78^{\mathrm{b}}$ & $63.2 \pm 2.95^{\mathrm{b}}$ & $63.4 \pm 2.78^{\mathrm{b}}$ \\
\hline$F$ value & $98 \pm 8.67^{\mathrm{a}}(-18)$ & $113 \pm 8.77^{\mathrm{b}}$ & $62.0 \pm 2.94^{\mathrm{b}}$ & $62.2 \pm 2.79^{\mathrm{b}}$ \\
\hline
\end{tabular}

Note: ${ }^{\mathrm{ns}}$ means are not significant at $\mathrm{p}=0.05 ; *$ significant at $\mathrm{p}=0.05$

Mean values and standard deviation ( $n=18$ for position of fruits in tree; $n=6$ for number of fruits per panicle); values followed by different letters within a column, for each factor, are significantly different at $\mathrm{p}=0.05$ (LSD test); $\mathrm{F}$ value $-F$ statistic for main effects from ANOVA 
Table 2. Effect of the position of fruits in citrus tree and the number of fruits per panicle on the weight (g) of pulp and peel of fruits $(\mathrm{g})$ - means from two seasons

\begin{tabular}{|c|c|c|c|c|}
\hline \multirow{2}{*}{$\begin{array}{l}\text { Position of fruits } \\
\text { in the tree }\end{array}$} & \multicolumn{2}{|c|}{ Weight of pulp (g) } & \multicolumn{2}{|c|}{ Weight of peel $(\mathrm{g})$} \\
\hline & $2014 / 2015$ & $2015 / 2016$ & $2014 / 2015$ & $2015 / 2016$ \\
\hline Outer & $88.4 \pm 3.90^{\mathrm{a}}$ & $88.6 \pm 4.86^{\mathrm{a}}$ & $20.5 \pm 2.89^{a}$ & $20.4 \pm 2.69^{a}$ \\
\hline Inner & $87.2 \pm 3.89^{\mathrm{a}}$ & $87.4 \pm 4.84^{\mathrm{a}}$ & $23.9 \pm 2.90^{\mathrm{a}}$ & $23.9 \pm 2.70^{\mathrm{a}}$ \\
\hline$F$ value & $0.10^{\mathrm{ns}}$ & $0.08^{\mathrm{ns}}$ & $4.2^{\mathrm{ns}}$ & $4.1^{\mathrm{ns}}$ \\
\hline \multicolumn{5}{|l|}{$\begin{array}{l}\text { Number of fruits } \\
\text { per panicle }\end{array}$} \\
\hline 1 & $95.5 \pm 4.92^{b}$ & $95.7 \pm 4.51^{b}$ & $23.4 \pm 4.63^{\mathrm{a}}$ & $23.4 \pm 2.74^{\mathrm{a}}$ \\
\hline 2 & $90.6 \pm 4.91^{b}(-15)$ & $90.9 \pm 4.49^{b}(-15)$ & $22.6 \pm 4.62^{\mathrm{a}}$ & $22.4 \pm 2.72^{\mathrm{a}}$ \\
\hline 3 & $77.4 \pm 3.99^{\mathrm{a}}(-19)$ & $77.5 \pm 3.22^{\mathrm{a}}(-19)$ & $20.5 \pm 4.61^{\mathrm{a}}$ & $20.5 \pm 2.71^{\mathrm{a}}$ \\
\hline$F$ value & $24.6^{*}$ & $26.8 *$ & $3.3^{\mathrm{ns}}$ & $3.4^{\mathrm{ns}}$ \\
\hline
\end{tabular}

For explanation see Table 1

Table 3. Content of total sugar, vitamin C, and total acid in citrus fruits as affected by position of fruits and number of fruits/panicle - means from two seasons

\begin{tabular}{|c|c|c|c|c|c|c|}
\hline \multirow{2}{*}{$\begin{array}{l}\text { Position of } \\
\text { fruits in the } \\
\text { tree }\end{array}$} & \multicolumn{2}{|c|}{ Total sugar $(\%)$} & \multicolumn{2}{|c|}{ Vitamin $C\left(\mathrm{mg} \cdot 100 \mathrm{~g}^{-1}\right)$} & \multicolumn{2}{|c|}{ Total acid $(\%)$} \\
\hline & $2014 / 2015$ & $2015 / 2016$ & $2014 / 2015$ & $2015 / 2016$ & $2014 / 2015$ & $2015 / 2016$ \\
\hline Outer & $7.49 \pm 0.64^{\mathrm{a}}$ & $7.52 \pm 0.61^{\mathrm{a}}$ & $19.6 \pm 2.43^{b}$ & $19.7 \pm 1.94^{b}$ & $0.56 \pm 0.068^{\mathrm{a}}$ & $0.56 \pm 0.065^{\mathrm{a}}$ \\
\hline Inner & $8.46 \pm 0.65^{\mathrm{a}}$ & $8.47 \pm 0.63^{\mathrm{a}}$ & $\begin{array}{c}16.6 \pm 2.03^{\mathrm{a}} \\
(-15)\end{array}$ & $\begin{array}{c}16.7 \pm 1.88^{\mathrm{a}} \\
(-15)\end{array}$ & $0.45 \pm 0.067^{\mathrm{a}}$ & $0.46 \pm 0.063^{\mathrm{a}}$ \\
\hline$F$ value & $4.3^{\mathrm{ns}}$ & $4.3^{\mathrm{ns}}$ & $8.0 *$ & $8.8^{*}$ & $4.4^{\mathrm{ns}}$ & $5.7^{\mathrm{ns}}$ \\
\hline \multicolumn{7}{|l|}{$\begin{array}{l}\text { Number of } \\
\text { fruits/panicle }\end{array}$} \\
\hline 1 & $8.02 \pm 0.29^{\mathrm{a}}$ & $8.02 \pm 0.25^{\mathrm{a}}$ & $16.9 \pm 2.22^{\mathrm{a}}$ & $17.0 \pm 2.06^{\mathrm{a}}$ & $0.45 \pm 0.083^{\mathrm{a}}$ & $0.46 \pm 0.078^{\mathrm{a}}$ \\
\hline 2 & $8.39 \pm 0.30^{\mathrm{a}}$ & $8.36 \pm 0.26^{\mathrm{a}}$ & $18.5 \pm 2.24^{\mathrm{a}}$ & $\begin{array}{l}18.6 \pm 2.08^{b} \\
\quad(+10)\end{array}$ & $\begin{array}{c}0.47 \pm 0.084^{\mathrm{ab}} \\
(+28)\end{array}$ & $\begin{array}{c}0.48 \pm 0.079^{\mathrm{ab}} \\
\quad(+25)\end{array}$ \\
\hline 3 & $7.51 \pm 0.28^{a}$ & $7.61 \pm 0.23^{\mathrm{a}}$ & $18.9 \pm 2.25^{\mathrm{a}}$ & $\begin{array}{c}18.9 \pm 2.09^{b} \\
(+10)\end{array}$ & $\begin{array}{c}0.60 \pm 0.085^{\mathrm{b}} \\
(+30)\end{array}$ & $\begin{array}{c}0.60 \pm 0.082^{\mathrm{a}} \\
\quad(+30)\end{array}$ \\
\hline$F$ value & $4.7^{\mathrm{ns}}$ & $3.6^{\mathrm{ns}}$ & $5.1^{\mathrm{ns}}$ & $5.7 *$ & $12.2^{*}$ & $15.2 *$ \\
\hline
\end{tabular}

For explanation see Table 1

\section{CONCLUSION}

The following conclusions can be drawn:

1. Position of fruits on the tree did not influence the weight and diameter of fruits, weight of fruit pulp, and contents of sugars and total acids.

2. Increased number of fruits per panicle decreased the weight and diameter of fruits and the weight of pulp but increased the contents of vitamin C and total acids.

\section{Acknowledgment}

The authors thank the Directorate General of Higher Education, Department of National Education for research funding as written in the implementation contract of a competitive loan from Research and Community Services No.3099/UN23.10/PN.01.00/2014. 


\section{REFERENCES}

Dennis F.G. Jr. 2000. The history of fruit thinning. Plant Growth Regulation 31: 1-16. DOI: 10.1023/a:1006330009160.

Dhillon W.S., Thakur A. 2014. Canopy management and effects of pruning on flowering tendencies in fruit trees. National Seminar-cum-Workshop on physiology of flowering in perennial fruit crops. Lucknow, India, pp. 182-201.

Ezeigbo O.R., Okike-Osisiogu F.U., Agomoh N.G., Anosike E.O., Asogu G.O. 2013. Determination of relative levels of vitamin $\mathrm{C}$ in different citrus fruits cultivated in Nigeria. International Journal of Science and Technoledge 1(4): 6-8.

Falivene S., Hardy S. 2008. Hand thinning citrus. New South Wales Department of Primary Industries. Prime Facts 789: 1-3.

Ghani A., Hussain M., Ikram M., Ahmad N.M.I., Khan A., Iftikhar M. et al. 2016. Comparative analysis of ascorbic acid concentration in two varieties of citrus (Citrus sinensis, Citrus limetta) collected from different tehsils of District Sargodha, Pakistan. Vitamins and Minerals 5(1); 138, 3 p. DOI: 10.4172/2376-1318.1000138.

Guardiola J.L., García-Luis A. 2000. Increasing fruit size in Citrus. Thinning and stimulation of fruit growth. Plant Growth Regulation 31: 121-132. DOI: 10.1023/a:1006339721880.

Iglesias D.J., Cercós M., Colmenero-Flores J.M., Naranjo M.A., Ríos G., Carrera E. et al. 2007. Physiology of citrus fruiting. Brazilian Journal of Plant Physiology 19(4): 333-362. DOI: 10.1590/s167704202007000400006.

Lee S.K., Kader A.A. 2000. Preharvest and postharvest factors influencing vitamin $\mathrm{C}$ content of horticultural crops. Postharvest Biology and Technology 20: 207-220. DOI: 10.1016/s0925-5214(00)00133-2.

Léchaudel M., Lopez-Lauri F., Vidal V., Sallanon H., Joas J. 2013. Response of the physiological parameters of mango fruit (transpiration, water relations and antioxidant system) to its light and temperature environmental. Journal of Plant Physiology 170(6): 567-576. DOI: 10.1016/j.jplph.2012.11.009.

Magwaza L.S., Mditshwa A., Tesfay S.Z., Opara U.L. 2017. An overview of preharvest factors affecting vitamin C content of citrus fruit. Scientia Horticulturae 216: 12 21. DOI: 10.1016/j.scienta.2016.12.021.

Massot C., Bancel D., Lopez Lauri F., Truffault V., Baldet P., Stevens R., Gautier H. 2013. High tem- perature inhibits ascorbate recycling and light stimulation of the ascorbate pool in tomato despite increased expression of biosynthesis genes. PLoS ONE 8, e84474, 13 p. DOI: 10.1371/journal.pone. 0084474.

Meir P., Kruijt B., Broadmeadow M., Barbosa E., Kull O., Carswell F. et al. 2002. Acclimation of photosynthetic capacity to irradiance in tree canopies in relation to leaf nitrogen concentration and leaf mass per unit area. Plant, Cell and Environment 25: 343 357. DOI: 10.1046/j.0016-8025.2001.00811.x.

Nartvaranant P. 2016. Effects of fruit thinning on fruit drop, leaf carbohydrates concentration, fruit carbohydrates concentration, leaf nutrient concentration and fruit quality in Pummelo cultivar Thong Dee. Songklanakarin Journal of Science and Technology 38(3): 249-255. DOI: 10.14456/sjst-psu.2016.34.

Ouma G. 2012. Fruit thinning with specific reference to citrus species: A review. Agriculture and Biology Journal of North America 3(4): 175-191. DOI: 10.5251/abjna.2012.3.4.175.191.

Racskó J. 2006. Crop load, fruit thinning and their effects on fruit quality of apple (Malus domestica Borkh.). Journal of Agricultural Sciences 24: 29-35.

Rahmawan M.I., Suparto S.R., Sakhidin 2015. Growth, fruit drop, and nutrition content of orange from the cluster that having different number of young fruits. Agrin 19(1): 29-36. [in Indonesian with English abstract]

Stover E. 2000. Relationship of flowering intensity and cropping in fruit species. HortTechnology 10(4): 729-732.

Sudarmadji S., Haryono B., Suhardi 1989. Analisa bahan makanan dan pertanian. University Gadjah Mada, Penerbit Liberty, Yogyakarta, Indonesia, 172 p. [in Indonesian]

Sutopo 2011. Rekomendasi Pemupukan untuk Tanaman Jeruk. Balai Penelitian Tanaman Jeruk dan Buah Subtropika (Balitjestro). [in Indonesian] https://kpricitrus.wordpress.com/2011/06/14/

Volz R.K., Ferguson I.B., Bowen J.H., Watkins C.B. 1993. Crop load effects on fruit mineral nutrition, maturity, fruiting and tree growth of 'Cox's Orange Pippin' apple. Journal of Horticultural Science 68: 127-137. DOI: 10.1080/00221589.1993.11516336.

Zhou G., Jin F., Wan M., Li M., Yang L., Ao X., Han C., $\mathrm{Xu}$ Q. 2014. Influence of the number of reserved fruit on fruit-bearing branch of early-maturing Citrus unshiu Marc. on fruit growth and development. Agricultural Science \& Technology 15(2): 238-242. 